九州大学学術情報リポジトリ

Kyushu University Institutional Repository

\title{
Evolutionary diversification of bruchine beetles : Climate-dependent traits and development associated with pest status
}

Tuda, Midori

Institute of Biological Control, Faculty of Agriculture, Kyushu University

http://hdl. handle. net/2324/25731

出版情報: Bulletin of Entomological Research. 101 (4)，pp.415-422，2011-08. Cambridge University Press

バージョン:

権利関係: (C) Cambridge University Press 2011 


\title{
Evolutionary diversification of bruchine beetles: climate-dependent traits and development associated with pest status
}

\author{
M. Tuda* \\ Institute of Biological Control, Faculty of Agriculture, Kyushu University, \\ Fukuoka 812-8581, Japan
}

\begin{abstract}
A number of insect species infest human households and stored foods and products, leading to their designation as pests. Until recently, little was known about the factors driving the evolution of pests that feed on stored dry foods. Here, I review the effects of changes in climate and species interactions on the evolution and ecology of beetles that feed on dried seeds/grains. My review focuses on evidence that the host utilization by part of the species in the subfamily Bruchinae (Chrysomelidae) is a preadaptation for utilizing stored dry seeds and grains, thus leading to their status as a pest. These and other stored product pest beetles retain a higher percentage of water in their body, relative to the water content of their diet, than beetles that feed on fresh crops. I review the studies that have documented adaptation, acclimation and polyphenetic response to high temperatures and desiccation and/or made direct comparisons between these traits between developmental stages, populations and among higher taxonomic groups. Finally, I review evidence for the effects of environmental change on insect host-parasitoid and competitor assemblages.
\end{abstract}

Keywords: Bruchidae, preadaptation, heat, stored crop pest, arid season, phytophagous insects

(Accepted 30 September 2010)

\section{Introduction}

A number of insect species infest human households and stored foods and products, leading to their designation as pests (Marlatt, 1896; Alfieri, 1931). These animals share a number of distinct biological characteristics which have brought about their widespread distribution. One of the most important characteristics is their tolerance to a wide range of physical environments. For example, some species are able to utilize foods that have a wide range of moisture content (Linsley, 1944). Other characteristics include polyphagy and aphagy (Linsley, 1944; Tuda et al., 2005). Despite the economic and social impact of these pests (up to 9\% loss in developed countries and up to $20 \%$, or more, loss in developing countries: Phillips \& Throne, 2010), little is known about the factors that

*Fax: +81-92-642-3040

E-mail: tuda@grt.kyushu-u.ac.jp drive their evolution. Here, I review the effects of species interactions and climate on the evolution and ecology of beetles (bruchine seed beetles, in particular; see also Labeyrie, 1981; Fujii et al., 1990; Yoshida, 1990). I also review the studies of adaptation, acclimation and polyphenetic response to high temperatures and desiccation and the evidence for the effects of environmental change on host-parasitoid and competitor assemblages.

\section{Evolution of dry food use as a preadaptation to becoming a stored food pest}

It has been hypothesized that the human cultivation of grains in tropical/subtropical climates promoted the evolution of pests that rely on stored grains/legumes for some part of their life cycle (Cotton, 1956). However, recent studies suggest that changes in climate and in host plant assemblages associated with different climates were a prerequisite for the evolution of host utilization in insects that are now considered 
to be stored grain pests (Tuda et al., 2006b). Furthermore, there is evidence that the species split between stored bean pests and that the non-pest sister species occurred long before the human cultivation of beans (Alvarez et al., 2005).

The majority of seed beetles from the subfamily Bruchinae (Coleoptera: Chrysomelidae) utilize the seeds of the bean family (Fabaceae) as larval hosts (Johnson, 1981). After hatching from eggs deposited on or near seeds by their mothers, the larvae feed and pupate inside the seeds. Partly because of this life cycle, some members of the subfamily are considered to be serious pests of leguminous plants. Utilization of dry beans for larval hosts is most likely, an ancestral trait in bruchine seed beetles (Tuda et al., 2006b). Interestingly though, some bruchines utilize only immature, soft seeds (Southgate, 1979; Decelle, 1981; Alvarez et al., 2005; Tuda et al., 2006b; M. Tuda, unpublished). It is unlikely that the evolution of the use of dry seeds was driven by the use of cultivated legumes. Instead, this trait is likely a preadaptation for becoming a pest of stored beans (Watanabe, 1985; Tuda et al., 2006b). We hypothesize that this unique feeding trait may be explained by climate (long, arid seasons) and the associated plant taxa, not their cultivation status. The long period of time in which seeds are available may also allow multivoltinism (Southgate, 1981; Ishihara, 1998; Alvarez et al., 2005). Our recent study is the first to test competing hypotheses about the evolution of dried food pests (Tuda et al., 2006b). Our data suggested that the length of the dry period contributed more to the evolution of a life cycle that incorporated the use of dry food than temperature per se. This is probably due to the long period of food availability associated with dry season (Tuda et al., 2006b). Although this host-utilization phenotype may be ancestral, it is not strictly phylogenetically constrained as it is observed sporadically throughout the bruchine subfamily (M. Tuda, unpublished). Recently, several closely related species of bruchine beetles that feed on either dry seeds or fresh seeds were identified (Tuda, 2003; Tuda \& Morimoto, 2004). A comparison of these species affords an opportunity to test the factor(s) driving the evolution of host-utilization traits that are associated with stored bean pests (Tuda, 2007).

Many pest insects of stored products were already preadapted to exploit the small quantities of naturally stored dry or rotten plant and animal materials, including dry seeds, fruits, pollen, dead insects, and hairs or feathers in the nests and webs of birds, mammals, spiders and insects (Linsley, 1944). Most of these insects are scavengers or predaceous, unlike bruchines. Therefore, the climate effect on the preadaptation suggested for bruchine beetles may not be applied to these insects. Furthermore, besides these natural causes, humans have likely had a considerable influence on the evolutionary processes. For example, the storage of large amounts of grain for long periods of time, particularly during World War I and II, may have promoted the adaptation of potential pests to storage conditions.

\section{Adaptation to arid climates}

The tolerance for changes in temperature and humidity varies among the developmental stages of insects, such as Drosophila (Krebs \& Loeschcke, 1995; Gilchrist et al., 1997), the kelp fly (Klok \& Chown, 2001) and Tribolium, a pest of stored, dried foods (Oosthuizen, 1935; Mahroof et al., 2003). As such, holometabolous insects and amphibians experience different habitat climates at each life-history stage. The egg and adult stages tend to be exposed to the ambient environment and may be tolerant of severe climate extremes (Howe \& Currie, 1964; Bale \& Hayward, 2010). A number of behavioral and physiological adaptations to aridity have been noted in these life stages. For example, some bruchines lay their eggs in layers or cover them with fecal material. This prevents the eggs from desiccation, as well as from egg parasitoids (Teran, 1962; Prevett, 1966; Janzen, 1971; Mitchell, 1977; Delobel et al., 1995; Tuda, 2007). The eggs are also tolerant to a wide range of both humidity and temperature (Howe \& Currie, 1964). Adults and larvae have a greater proportion of water in the bound form than the pupae (Kagoshima, Ishibashi, Tuda, \& Iwaya-Inoue, unpublished). Most bruchine beetles enter diapause (reproductive quiescence) as adults (Utida, 1954; Sano, 1967; Ouedraogo et al., 1991; Amevoin et al., 2005; Appleby \& Credland, 2007; review by Bell, 1994), larvae (Donahaye et al., 1966; Shimada \& Ishihara, 1991) or both (Kurota, 2004). This phenomenon has also been reported in other beetle species that feed on dry, stored foods (review by Bell, 1994). The absence of diapause during the pupal stage is common among beetles, but not in other orders (Leather et al., 1993). This suggests that the physiological tolerance of beetles to extreme temperatures differs among the developmental stages (Mahroof et al., 2003). This difference may, in part, be a by-product of morphological reorganization, with little or no evolutionary significance (Bowler \& Terblanche, 2008). However, there is evidence that the expression of at least one of the genes encoding heat-shock proteins is down-regulated during the pupal (and late larval) stages in the stored pest beetle, Tribolium castaneum (Mahroof et al., 2005).

A classic physiological study by Robinson (1928) revealed that stored grain pest beetles retain disproportionately high levels of water in their body relative to the dried grains they feed on (fig. 1). The same is true for bruchine beetles. For example, larvae of Callosobruchus beetles feed on dry beans, whereas those of Bruchus rufimanus feed only on immature beans. Despite the difference in water content of the food source, both species have a similar proportion of body water (fig. 1). Furthermore, in these and other stored-product pests, the majority of body water is conserved in the bound form to minimize its loss (fig. 2) (Robinson, 1928). The cells of all living tissues contain millions of minute colloidal particles, which attract and bind water as a film on their surfaces. The water, thus bound, is held by the colloidal bodies with a powerful force (Robinson, 1928). By conserving water in this less mobile form, the insects gain resistance against both dry and cold environments (Robinson, 1927; Block, 1996). Similarly, heatresistant individuals of $C$. chinensis are characterized by longer adult life duration in very dry air (Kiyoku, 1962). This 'side effect' of adaptation to arid environments is seen in Callosobruchus beetles. In some species, the use of dry beans appears to have promoted a habitat shift (or expansion) from subtropical to temperate regions (Tuda et al., 2006b). Furthermore, the mechanisms proposed for insect mortality at high temperatures are the same as those for low temperatures (Tauber \& Tauber, 1986; Fields, 1992). These include changes in membrane lipid property (Gibbs, 1998; Patel et al., 2001), rate imbalances (Hochachka \& Somero, 1984; Fields, 1992), perturbation of ionic activities (CloudsleyThompson, 1962; Mullins, 1985) and desiccation (CloudsleyThompson, 1962; Fields, 1992).

Behavioral adaptation to aridity is observed in C. maculatus. Females mate more frequently under water deficiency, presumably because they can obtain a water source from male 


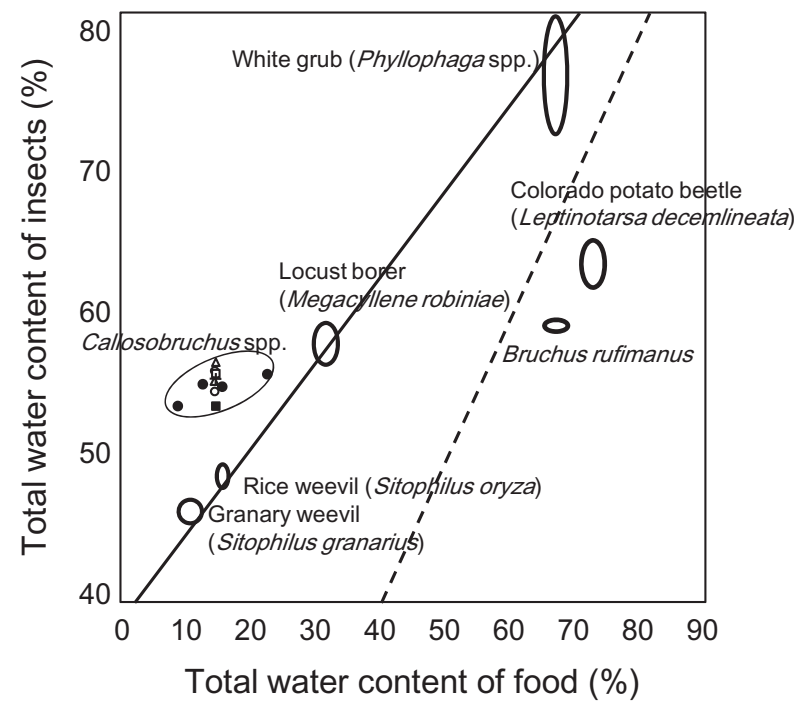

Fig. 1. Relationship between the water content of insects and their food (only Coleoptera are shown, modified from Robinson 1928, with additional data). The examples on the upper side of the broken line indicate that the water content of the insects is greater than that of the food. Granary weevil, rice weevil (Curculionidae) and Callosobruchus beetles (Chrysomelidae: Bruchinae) are stored seed/grain pests, whereas the Colorado potato beetle (Chrysomelidae), locust borer (Cerambycidae), white grub (Scarabaeidae) (Robinson, 1928) and broad bean beetle, Bruchus rufimanus (Chrysomelidae: Bruchinae) (Kagoshima \& Tuda, unpublished data) are pests of fresh vegetables and trees, at one or more life stages. •, Callosobruchus chinensis (Ishii, 1952); $O$, C. chinensis; $\Delta$, C. maculatus; $\square$, C. analis; - C. phaseoli; + , Zabrotes subfasciatus (Utida, 1966). The data were collected from the adults of all species except for the white grub (larvae) (Robinson, 1928).

ejaculates (Edvardsson, 2007). They also prefer drier beans for oviposition (Hudaib et al., 2010).

\section{Acclimation and adaptation to high temperatures}

Mellanby (1954) may have been the first author to demonstrate thermal acclimation at high temperatures in insects. Mealworm, Tenebrio molitor, larvae that were acclimated to temperatures of 37 and $30^{\circ} \mathrm{C}$ died at 44 and $42^{\circ} \mathrm{C}$, respectively, supporting the 'beneficial acclimation' hypothesis (Leroi et al., 1994). Using C. chinensis, Kiyoku (1960) observed acclimation and adaptation to high temperature $\left(35^{\circ} \mathrm{C}\right)$ in support of this hypothesis. However, the 'beneficial acclimation' hypothesis has been challenged in the latest decade. For example, thermal adaptation (or acclimatization) to a habitat was examined by exposing the bruchine beetle Stator limbatus to a range of temperatures (Stillwell \& Fox, 2005). Exposure to (and acclimation to) high temperatures during the immature stages of several species of bruchines leads to a general reduction in fecundity, irrespective of the tested oviposition temperature (Ishikura, 1939; El-Sawaf, 1956; Stillwell \& Fox, 2005). This reduction in fecundity seemingly supports 'colder is better' hypothesis (Huey et al., 1999), which is induced by a reduction in body size as is typical in ectothermic organisms (Atkinson, 1994). Overall, either 'colder is better' hypothesis or 'optimal developmental temperature' hypothesis (Cohet \& David, 1978; Huey et al., 1999 or 'deleterious acclimation' hypothesis (Loeschcke

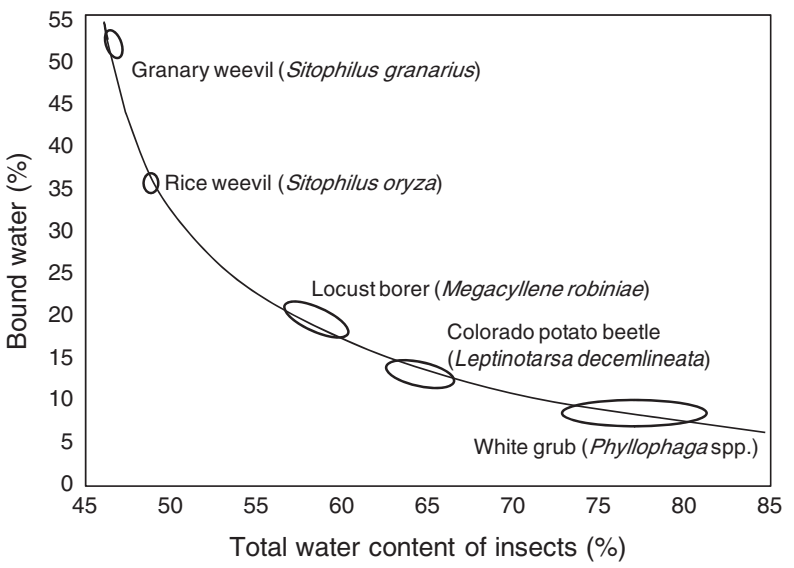

Fig. 2. Relationship between total water content and the percentage of water bound by colloids (only Coleoptera are shown, modified from Robinson, 1928). The species that live on dry food and have a small percentage of water in their own tissues retain a large percentage of water in the bound form. The data were collected from the same developmental stages as in fig. 1 for each species.

\& Hoffmann, 2002; Wilson \& Franklin, 2002) seems to be supported both in S. limbatus (Stillwell \& Fox, 2005) and Zabrotes subfasciatus (Howe \& Currie, 1964). Acclimation of other insects that feed on stored products depends on the range of the highest temperatures, and this is ascribed to thermal effect on biochemical process (Fields, 1992). Survival at very high, sublethal temperatures $\left(40-50^{\circ} \mathrm{C}\right)$ may be improved by acclimation at high temperatures. However, survival at extremely high, lethal temperatures $\left(55-80^{\circ} \mathrm{C}\right)$ is not affected by acclimation. Within this temperature range $\left(56-60^{\circ} \mathrm{C}\right)$, denaturation and inactivation of pyruvate kinase, a key enzyme in glycolysis, is induced and is likely responsible for mortality (Hochachka \& Somero, 1984).

\section{Effect of climate and the host plants on polyphenism, population density and competitive/predatory interactions}

Climate does not act alone on phytophagous insects. The host plants also alter the fitness of insect herbivores in a predictable manner. By selecting different host plants, C. maculatus is able to survive over a wider range of temperatures and humidity than is optimal in a limited range of climate (Howe \& Currie, 1964). Stillwell et al. (2007b) noted an increase in fitness at high temperatures for traits associated with body size (i.e. growth rate, fecundity and body size itself) but not for larval survival or development time. Temperature has a significant effect on the success of small males during intraspecific competition for mates (Moya-Larano et al., 2007). Both temperature and the host plant type affect the size of the nuptial gift, as seminal fluids (ejaculates), offered by the males (Fox et al., 2006). Furthermore, it appears that there is an interaction effect between these two variables. Variation in the body size of $S$. limbatus throughout its range was attributed to differences in host plant seed size, moisture (humidity) and seasonality (variation in humidity, precipitation and temperature), but not to mean temperature (Stillwell et al., 2007a). Moisture also partially explains the geographic variation in sexual dimorphism (Stillwell et al., 2007a). Conversely, in 
C. maculatus, experiments at a constant temperature suggest that higher temperatures induce greater sexual dimorphism in body size (Stillwell \& Fox, 2007). This is probably caused by sexual conflicts related to fitness optimization strategies, which may increase population fitness (Rankin \& Arnqvist, 2008; Arnqvist \& Tuda, 2010). Early-emerging (smaller) males are more likely to find mates, particularly if the females are ready to mate soon after emergence (Rönn et al., 2008) and are reluctant, or refuse, to mate more than once (Edvardsson \& Tregenza, 2005; Sakurai \& Kasuya, 2008). However, larger females tend to take longer to develop and are more fecund and, thus, fitter (Yanagi \& Miyatake, 2002; Vamosi, 2005; Vamosi \& Lesack, 2007), especially when resource replacement cycle is long (Sibly et al., 1991).

The optimal temperature for rapid development in insects tends to be higher than the optimal temperature for survival and reproduction (Howe \& Currie, 1964; Braby \& Jones, 1994). The optimal humidity is typically high for development, survival and reproduction. However, very high humidity levels enhance fungus development and increase mortality in immature beetles. The effects of temperature/humidity on populations and/or species should, therefore, be compared on lifetime fitness (Deutsch et al., 2008; Yanagi \& Tuda, 2010).

There are two adult morphs, the flight form (or active form in reproductive diapause) and non-flight form, in some bruchine seed beetles. High or increased temperature, long thermoperiods, extreme day-lengths, high seed water content and high larval density induce the flight form of C. maculatus (Utida, 1954, 1965, 1969; Sano, 1967; Sano-Fujii, 1984; Ouedraogo et al., 1991). The flight form is partially heritable (Caswell, 1960; Sano-Fujii, 1986). These environmental factors also have a similar effect on induction of the active morph in other species congeneric to $C$. maculatus (temperature effect in C. subinnotatus (Appleby \& Credland, 2007); density effect in C. subinnotatus and C. rhodesianus (Amevoin et al., 2005; Appleby \& Credland, 2007); and seed water content in C. chinensis (Nahdy et al., 1999)).

Most phytophagous arthropods engage in predator-prey or parasitoid-host interactions in nature. Predictions regarding how climate change will alter these interactions are crucial for conservation of biological diversity and for biological control practices. An understanding of the effects of climate change on these interactions in wild populations relies on direct observation and analysis of field populations with the associated climate data (Tuda \& Shima, 2002; Tuda et al., 2006a). Alternatively, demographic experiments that use model species provide a useful tool for understanding the general rules governing the effects of climate on whole ecosystems.

Studies have shown that just a $2{ }^{\circ} \mathrm{C}$ increase in the temperature reduces the population size of seed beetles via a decrease in density-dependent rates of egg hatching and larval survival (Tuda, 1993; Tuda \& Shimada, 1993). Furthermore, such an increase in temperature also affects the coexistence of the seed beetle and its parasitoid populations (Tuda \& Shimada, 1995, 2005). However, the effect is highly species specific. Both the host and the parasitoid will coexist if the functional response of the parasitoid stabilizes the hostparasitoid population dynamics following an increase in temperature (M. Tuda, unpublished data).

Phytophagous insects also participate in competitive interactions, although competition may occur less frequently than predation (Jermy \& Szentesi, 2003). Changes in climate (e.g. a $2^{\circ} \mathrm{C}$ rise and humidity change) alter the interspecific competitive success of two Callosobruchus beetle species, which may be ascribed by different environmental effects on development time and fecundity between the two species (Fujii, 1967). Furthermore, Davis et al. (1998) showed that allowing dispersal along temperature clines altered the outcome of competition and species distribution in laboratoryreared Drosophila metapopulations.

\section{Genetics of thermal adaptation}

Development time and metabolic rate of $C$. maculatus are affected by temperature and by the interaction between mitochondrial haplotype and nuclear genotype (or mitonuclear interaction) (Dowling et al., 2007; Arnqvist et al., 2010). Such mitonuclear interactions (Ballard \& Rand, 2005) may be ubiquitous in insect thermal response. There is evidence that mtDNA transmission rates of Drosophila is temperature dependent (Nagata \& Matsuura, 1991) and that nuclear genome is involved in the temperature dependency (Doi et al., 1999). Although these studies using a model beetle shed light on the genetic background of the thermal response in beetles, our understanding of the genetic mechanisms controlling thermal adaptation is poor. Thus, this area of research offers considerable promise in the future.

\section{Future directions}

This review focused on climate effects on the evolution, developmental stages, variation within and among taxonomic groups, species interactions and coexistence in holometabolous insects, particularly beetles. Genetic effects on physiological plasticity and adaptation tend to be underestimated in previous studies, except for some that have used model organisms such as Drosophila (Hoffmann et al., 2003) and Arabidopsis (Siomos, 2009). For well-studied laboratory model insects, however, extra caution must be paid to eliminate bottleneck events and artificial selection due to laboratory conditions and rearing. Populations that were reared in a large batch for a small number of generations $(<<20)$ (for timescale of selection, see Tuda (1998) and Tuda \& Iwasa (1998)) or several smaller populations with a moderate gene flow may be used.

Recent advances in molecular methods will improve our understanding of adaptation and acclimation to climate. On one hand, studies on molecular mechanisms of adaptation/ acclimation to climate changes in beetles might benefit from DNA sequence data of a stored pest beetle, T. castaneum (Tribolium Genome Sequencing Consortium, 2008). For example, an evolutionary process may be uncovered for the close correlation between enzyme genotypes and the expression of a heat shock protein in a leaf beetle, Chrysomela aeneicollis (Dahlhoff \& Rank, 2000). In addition, approaches using phylogeny-based inference may improve the ability to distinguish between ecological plasticity and phylogenetic signals in climate-dependent traits. Comparative methods, such as have been used to describe the distribution of the variation in thermal tolerance at different levels of taxonomic hierarchy (Chown, 2001), may employ the molecularphylogeny-based hypothesis testing.

Quantification of the effects of global climate changes will be needed to predict future changes in phenology (Doi et al., 2010; Musolin et al., 2010), dispersal (Berg et al., 2010; Srygley et al., 2010), their synchronization with interacting species (Yukawa \& Akimoto, 2006; Hance et al., 2007; van Asch \& Visser, 2007; Klapwijk et al., 2010) and their 
population-dynamic consequences (Gilg et al., 2009) at local and regional scales (Kiritani, 2006; Tabachnick, 2010). A number of climate models predict that several regions of the world will experience more or more severe droughts as a result of rises in atmospheric $\mathrm{CO}_{2}$ and global temperature (Solomon et al., 2009; Xie et al., 2010). In these regions, particular attention should be paid to monitor any increase in the density and diversity of herbivorous insects, including stored crop pests.

\section{Acknowledgements}

This work was supported by Grants-in-Aid for Scientific Research from JSPS.

\section{References}

Alfieri, A. (1931) Les insects de la tombe de Toutankhamon. Bulletin de la Société Royale Entomologique d'Égypte 3-4, 188189.

Alvarez, N., McKey, D., Hossaert-McKey, M., Born, C., Mercier, L. \& Benrey, B. (2005) Ancient and recent evolutionary history of the bruchid beetle, Acanthoscelides obtectus Say, a cosmopolitan pest of beans. Molecular Ecology 14, 1015-1024.

Amevoin, K., Glitho, I.A., Monge, J.P. \& Huignard, J. (2005) Why Callosobruchus rhodesianus causes limited damage during storage of cowpea seeds in a tropical humid zone in Togo. Entomologia Experimentalis et Applicata 116, 175-182.

Appleby, J.H. \& Credland, P.F. (2007) The role of temperature and larval crowding in morph determination in a tropical beetle, Callosobruchus subinnotatus. Journal of Insect Physiology 53, 983-993.

Arnqvist, G. \& Tuda, M. (2010) Sexual conflict and the gender load: correlated evolution between population fitness and sexual dimorphism in seed beetles. Proceedings of the Royal Society, Series B 277, 1345-1352.

Arnqvist, G., Dowling, D.K., Eady, P., Gay, L., Tregenza, T., Tuda, M. \& Hosken, D.J. (2010) The genetic architecture of metabolic rate: environment specific epistasis between mitochondrial and nuclear genes in an insect. Evolution 64, 3354-3363.

Atkinson, D. (1994) Temperature and organism size: a biological law for ectotherms? Advances in Ecological Research 25, 1-58.

Bale, J.S. \& Hayward, S.A.L. (2010) Insect overwintering in a changing climate. Journal of Experimental Biology 213, 980-994.

Ballard, J.W.O. \& Rand, D.M. (2005) The population biology of mitochondrial DNA and its phylogenetic implications. Annual Review of Ecology, Evolution and Systematics 36, 621642.

Bell, C.H. (1994) A review of diapause in stored-product insects. Journal of Stored Products Research 30, 99-120.

Berg, M.P., Kiers, E.T., Driessen, G., van der Heijden, M., Kooi, B.W., Kuenen, F., Liefting, M., Verhoef, H.A. \& Ellers, J. (2010) Adapt or disperse: understanding species persistence in a changing world. Global Change Biology 16, 587-598.

Block, W. (1996) Cold or drought: the lesser of two evils for terrestrial arthropods? European Journal of Entomology 93, 325-339.

Bowler, K. \& Terblanche, J.S. (2008) Insect thermal tolerance: what is the role of ontogeny, ageing and senescence? Biological Reviews 83, 339-355.
Braby, M.F. \& Jones, R.E. (1994) Effects of temperature and hostplants on survival, development and body size in three tropical satyrine butterflies from north-eastern Australia. Australian Journal of Zoology 42, 195-213.

Caswell, G.H. (1960) Observations on an abnormal form of Callosobruchus maculatus (F.). Bulletin of Entomological Research 50, 671-680.

Chown, S.L. (2001) Physiological variation in insects: hierarchical levels and implications. Journal of Insect Physiology 47, 649-660.

Cloudsley-Thompson, J.L. (1962) Lethal temperatures of some desert arthropods and the mechanism of heat death. Entomologia Experimentalis et Applicata 5, 270-280.

Cohet, Y. \& David, J. (1978) Control of adult reproductive potential by pre-imaginal thermal conditions; a study in Drosophila melanogaster. Oecologia 36, 295-306.

Cotton, R.T. (1956) Insects Pests of Stored Grain and Grain Products. Minneapolis, MN, USA, Burgess.

Dahlhoff, E.P. \& Rank, N.E. (2000) Functional and physiological consequences of genetic variation at phosphoglucose isomerase: Heat shock protein expression is related to enzyme genotype in a montane beetle. Proceedings of the National Academy of Sciences USA 97, 10056-10061.

Davis, A.J., Lawton, J.H., Shorrocks, B. \& Jenkinson, L.S. (1998) Individualistic species responses invalidate simple physiological models of community dynamics under global environmental change. Journal of Animal Ecology 67, 600-612.

Decelle, J. (1981) Bruchidae related to grain legumes in the Afro-tropical area. pp. 193-197 in Labeyrie, V. (Ed.) The Ecology of Bruchids Attacking Legumes (Pulses). The Hague, The Netherlands, Dr W. Junk Publishers.

Delobel, A., Couturier, G., Kahn, F. \& Nilsson, J.A. (1995) Trophic relationships between palms and bruchids (Coleoptera, Bruchidae, Pachymerini) in Peruvian Amazonia. Amazoniana 13, 209-219.

Deutsch, C.A., Tewksbury, J.J., Huey, R.B., Sheldon, K.S., Ghalambor, C.K., Haak, D.C. \& Martin, P.R. (2008) Impacts of climate warming on terrestrial ectotherms across latitude. Proceedings of the National Academy of Sciences USA 105, 6668-6672.

Doi, A., Suzuki, H. \& Matsuura, E.T. (1999) Genetic analysis of temperature-dependent transmission of mitochondrial DNA in Drosophila. Heredity 82, 555-560.

Doi, H., Takahashi, M. \& Katano, I. (2010) Genetic diversity increases regional variation in phenological dates in response to climate change. Global Change Biology 16, 373-379.

Donahaye, E., Navarro, S. \& Calderon, M. (1966) Observations on the life cycle of Caryedon gonagra (F.) on its natural host in Israel, Acacia spirocarpa and A. tortilis. Tropical Science 8, 85-89.

Dowling, D.K., Abiega, K.C. \& Arnqvist, G. (2007) Temperaturespecific outcomes of cytoplasmic-nuclear interactions on egg-to-adult development time in seed beetles. Evolution 61, 194-201.

Edvardsson, M. (2007) Female Callosobruchus maculatus mate when they are thirsty: resource-rich ejaculates as mating effort in a beetle. Animal Behaviour 74, 183-188.

Edvardsson, M. \& Tregenza, T. (2005) Why do male Callosobruchus maculatus harm their mates? Behavioral Ecology 16, 788-793.

El-Sawaf, S.K. (1956) Some factors affecting the longevity, oviposition and rate of development in the southern 
cowpea weevil, Callosobruchus maculatus F. (Coleoptera: Bruchidae). Bulletin de la. Societe Entomologique d'Egypte 40, 29-95.

Fields, P.G. (1992) The control of stored-product insects and mites with extreme temperatures. Journal of Stored Products Research 28, 89-118.

Fox, C.W., Stillwell, R.C., Wallin, W.G. \& Hitchcock, L.J. (2006) Temperature and host species affect nuptial gift size in a seed-feeding beetle. Functional Ecology 20, 1003-1011.

Fujii, K. (1967) Studies on interspecies competition between the azuki bean weevil, Callosobruchus chinensis, and the southern cowpea weevil, C. maculatus. II. Competition under different environmental conditions. Researches on Population Ecology 9, 192-200.

Fujii, K., Gatehouse, A.M.R., Mitchell, R., Johnson, C.D. \& Yoshida, Y. (1990) Bruchids and Legumes: Economics, Ecology and Coevolution. Dordrecht, The Netherlands, Kluwer Academic Publishers.

Gibbs, A.G. (1998) The role of lipid physical properties in lipid barriers. American Zoologist 38, 268-279.

Gilchrist, G.W., Huey, R.B. \& Partridge, L. (1997) Thermal sensitivity of Drosophila melanogaster: Evolutionary responses of adults and eggs to laboratory natural selection at different temperatures. Physiological Zoology 70, 403-414.

Gilg, O., Sittler, B. \& Hanski, I. (2009) Climate change and cyclic predator-prey population dynamics in the high Arctic. Global Change Biology 15, 2634-2652.

Hance, T., van Baaren, J., Vernon, P. \& Boivin, G. (2007) Impact of extreme temperatures on parasitoids in a climate change perspective. Annual Review of Entomology 52, 107-126.

Hochachka, P.W. \& Somero, G.N. (1984) Biochemical Adaptation. Princeton, NJ, USA, Princeton University Press.

Hoffmann, A.A., Sorensen, J.G. \& Loeschcke, V. (2003) Adaptation of Drosophila to temperature extremes: bringing together quantitative and molecular approaches. Journal of Thermal Biology 28, 175-216.

Howe, R.W. \& Currie, J.E. (1964) Some laboratory observations on the rates of development, mortality and oviposition of several species of Bruchidae breeding in stored pulses. Bulletin of Entomology Research 55, 437-477.

Hudaib, T., Hayes, W., Brown, S. \& Eady, P.E. (2010) Effect of seed moisture content and d-limonene on oviposition decisions of the seed beetle Callosobruchus maculatus. Entomologia Experimentalis et Applicata 137, 120-125.

Huey, R.B., Berrigan, D., Gilchrist, G.W. \& Herron, J.C. (1999) Testing the adaptive significance of acclimation: a strong inference approach. American Zoologist 39, 323-336.

Ishihara, M. (1998) Geographical variation in insect developmental period: effect of host plant phenology on the life cycle of the bruchid seed feeder Kytorhinus sharpianus. Entomologia Experimentalis et Applicata 87, 311-319.

Ishii, S. (1952) Studies on the host preference of the cowpea weevil (Callosobruchus chinensis. L.). Bulletin of National Institute of Agricultural Science, Series C 1, 185-256 (in Japanese with English summary).

Ishikura, S. (1939) Influence of temperature and humidity at the developmental period upon the oviposition of Bruchus chinensis L. Oyo Dobutsu Zasshi 11, 41-52 (in Japanese).

Janzen, D.H. (1971) Seed predation by animals. Annual Review of Ecology and Systematics 2, 465-492.

Jermy, T. \& Szentesi, A. (2003) Evolutionary aspects of host plant specialisation - a study on bruchids (Coleoptera: Bruchidae). Oikos 101, 196-204.
Johnson, C.D. (1981) Seed beetle host specificity and the systematics of the Leguminosae. pp. 995-1027 in Polhill, R.M. \& Raven, P.H. (Eds) Advances in Legume Systematics, Part 2. Kew, UK, Royal Botanical Gardens.

Kiritani, K. (2006) Predicting impacts of global warming on population dynamics and distribution of arthropods in Japan. Population Ecology 48, 5-12.

Kiyoku, M. (1960) Experimental studies on the influence of an abnormally high temperature upon some biological characters in insects survived the heat-treatment and those in their offsprings. Scientific Reports of the Faculty of Agriculture Okayama University 16, 25-32.

Kiyoku, M. (1962) Studies on the lethal action of abnormally high temperature on insects, XVIII. general consideration and conclusions on the results of the serial studies published hitherto. Scientific Reports of the Faculty of Agriculture Okayama University 19, 17-28.

Klapwijk, M.J., Groebler, B.C., Ward, K., Wheeler, D. \& Lewis, O.T. (2010) Influence of experimental warming and shading on host-parasitoid synchrony. Global Change Biology 16, 102-112.

Klok, C.J. \& Chown, S.L. (2001) Critical thermal limits, temperature tolerance and water balance of a sub-Antarctic kelp fly, Paractora druexi (Diptera: Helcomyzidae). Journal of Insect Physiology 47, 95-109.

Krebs, R.A. \& Loeschcke, V. (1995) Resistance to thermal stress in preadult Drosophila buzzattii: Variation among populations and changes in relative resistance across life stages. Biological Journal of the Linnean Society 56, 517-531.

Kurota, H. (2004) Overwintering strategies depending on high cold hardiness in nondiapause stages in Bruchidius dorsalis (Coleoptera: Bruchidae). Environmental Entomology 33, 1163-1168.

Labeyrie, V. (1981) The ecology of bruchids attacking legumes (pulses). The Hague, Dr W Junk Publishers.

Leather, S.R., Walters, K.F.A. \& Bale, J.S. (1993) The Ecology of Insect Overwintering. Cambridge, UK, Cambridge University Press.

Leroi, A.M., Bennett, A.F. \& Lenski, R.E. (1994) Temperature acclimation and competitive fitness: an experimental test of the beneficial acclimation assumption. Proceedings of the National Academy of Sciences USA 91, 1917-1921.

Linsley, E.G. (1944) Natural sources, habitats and reservoirs of insects associated with stored food products. Hilgardia 16, 187-224.

Loeschcke, V. \& Hoffmann, A.A. (2002) The detrimental acclimation hypothesis. Trends in Ecology \& Evolution 17, 407-408.

Mahroof, R., Subramanyam, B., Throne, J.E. \& Menon, A. (2003) Time-mortality relationships for Tribolium castaneum (Coleoptera: Tenebrionidae) life stages exposed to elevated temperatures. Journal of Economic Entomology 96, 1345-1351.

Mahroof, R., Zhu, K.Y., Neven, L., Subramanyam, B. \& Bai, J. (2005) Expression patterns of three heat shock protein 70 genes among developmental stages of the red flour beetle Tribolium castaneum (Coleoptera: Tenebrionidae). Comparative Biochemistry and Physiology A 141, 247-256.

Marlatt, C.L. (1896) The clothes moths. United States Department of Agriculture Division of Entomology Bulletin 4(n.s.), 63-69.

Mellanby, K. (1954) Acclimatization and the thermal death point in insects. Nature 173, 582-583.

Mitchell, R. (1977) Bruchid beetles and seed packaging by Palo Verde. Ecology 58, 644-651. 
Moya-Larano, J., El-Sayyid, M.E.T. \& Fox, C.W. (2007) Smaller beetles are better scramble competitors at cooler temperatures. Biology Letters 3, 475-478.

Mullins, D.E. (1985) Chemistry and physiology of the haemolymph. pp. 355-400 in Kerkut, G.A. \& Gilbert, L.I. (Eds) Comprehensive Insects Physiology. Oxford, UK, Pergamon Press.

Musolin, D.L., Tougou, D. \& Fujisaki, K. (2010) Too hot to handle? Phenological and life-history responses to simulated climate change of the southern green stink bug Nezara viridula (Heteroptera: Pentatomidae). Global Change Biology 16, 73-87.

Nagata, Y. \& Matsuura, E.T. (1991) Temperature dependency of electron-transport activity in mitochondria with exogenous mitochondrial DNA in Drosophila. Japanese Journal of Genetics 66, 255-261.

Nahdy, M.S., Silim, S.N. \& Ellis, R.H. (1999) Effect of field infestations of immature pigeonpea (Cajanus cajan (L.) Millsp.) pods on production of active (flight) and sedentary (flightless) morphs of Callosobruchus chinensis (L.). Journal of Stored Products Research 35, 339-354.

Oosthuizen, M.J. (1935) The effect of high temperature on the confused flour beetle. Minnesota Technological Bulletin $107,1-45$.

Ouedraogo, P.A., Monge, J.P. \& Huignard, J. (1991) Importance of temperature and seed water content on the induction of imaginal polymorphism in Callosobruchus maculatus. Entomologia Experimentalis et Applicata 59, 59-66.

Patel, S., Nelson, D.R. \& Gibbs, A.G. (2001) Chemical and physical analyses of wax ester properties. Journal of Insect Science 1(4), 7pp.

Phillips, T.W. \& Throne, J.E. (2010) Biorational approaches to managing stored-product insects. Annual Review of Entomology 55, 375-397.

Prevett, P.F. (1966) Observations on biology in the genus Caryedon Schoenherr (Coleoptera: Bruchidae) in Northern Nigeria with a list of associated parasitic Hymenoptera. Proceedings of the Royal Entomological Society of London, Series A 41, 9-16.

Rankin, D.J. \& Arnqvist, G. (2008) Sexual dimorphism is associated with population fitness in the seed beetle Callosobruchus maculatus. Evolution 62, 622-630.

Robinson, W.M. (1927) Water binding capacity of colloids a definite factor in winter hardiness of insects. Journal of Economic Entomology 20, 80-88.

Robinson, W.M. (1928) Water conservation in insects. Journal of Economic Entomology 21, 898-902.

Rönn, J.L., Katvala, M. \& Arnqvist, G. (2008) Interspecific variation in ejaculate allocation and associated effects on female fitness in seed beetles. Journal of Evolutionary Biology 21, 461-470.

Sakurai, G. \& Kasuya, E. (2008) Different female mating rates in different populations do not reflect the benefits the females gain from polyandry in the adzuki bean beetle. Journal of Ethology 26, 93-98.

Sano, I. (1967) Density effect and environmental temperature as the factors producing the active form of Callosobruchus maculatus (F.) (Coleoptera: Bruchidae). Journal of Stored Products Research 2, 187-195.

Sano-Fujii, I. (1984) Effect of bean water content on the production of the active form of Callosobruchus maculatus (F.) (Coleoptera: Bruchidae). Journal of Stored Products Research 20, 153-161.

Sano-Fujii, I. (1986) The genetic basis of the production of the active form of Callosobruchus maculatus (F.)
(Coleoptera: Bruchidae). Journal of Stored Products Research 22, 115-123.

Shimada, M. \& Ishihara, M. (1991) Two types of overwintering larvae in a wild multivoltine bruchid, Kytorhinus sharpianus Bridwell (Coleoptera, Bruchidae). Applied Entomology and Zoology 26, 289-297.

Sibly, R.M., Smith, R.H. \& Moller, H. (1991) Evolutionary demography of a bruchid beetle. 4. genetic trade-off, stabilizing selection and a model of optimal body size. Functional Ecology 5, 594-601.

Siomos, M.F. (2009) Shaped by the environment - adaptation in plants. FEBS Journal 276, 4705-4714.

Solomon, S., Plattner, G.K., Knutti, R. \& Friedlingstein, P. (2009) Irreversible climate change due to carbon dioxide emissions. Proceedings of the National Academy of Sciences USA 106, 1704-1709.

Southgate, B.J. (1979) Biology of the Bruchidae. Annual Review of Entomology 24, 449-473.

Southgate, B.J. (1981) Univoltine and multivoltine cycles: their significance. pp. 17-22 in Labeyrie, V. (Ed.) The Ecology of Bruchids Attacking Legumes (Pulses). The Hague, The Netherlands, Dr W. Junk Publishers.

Srygley, R.B., Dudley, R., Oliveira, E.G., Aizprua, R., Pelaez, N. Z. \& Riveros, A.J. (2010) El Nino and dry season rainfall influence hostplant phenology and an annual butterfly migration from Neotropical wet to dry forests. Global Change Biology 16, 936-945.

Stillwell, R.C. \& Fox, C.W. (2005) Complex patterns of phenotypic plasticity: Interactive effects of temperature during rearing and oviposition. Ecology 86, 924-934.

Stillwell, R.C. \& Fox, C.W. (2007) Environmental effects on sexual size dimorphism of a seed-feeding beetle. Oecologia 153, 273-280.

Stillwell, R.C., Morse, G.E. \& Fox, C.W. (2007a) Geographic variation in body size and sexual size dimorphism of a seed-feeding beetle. American Naturalist 170, 358-369.

Stillwell, R.C., Wallin, W.G. \& Fox, C.W. (2007b) Phenotypic plasticity in a complex world: interactive effects of food and temperature on fitness components of a seed beetle. Oecologia 153, 309-321.

Tabachnick, W.J. (2010) Challenges in predicting climate and environmental effects on vector-borne disease episystems in a changing world. Journal of Experimental Biology 213, 946-954.

Tauber, M.J. \& Tauber, C.A. (1986) Seasonal Adaptation of Insects. Oxford, UK, Oxford University Press.

Teran, A.L. (1962) Observaciones sobre Bruchidae del Noroeste Argentino. Acta Zoologica Lilloana 18, 211-242.

Tribolium Genome Sequencing Consortium (2008) The genome of the model beetle and pest. Tribolium castaneum. Nature 452, 949-955.

Tuda, M. (1993) Density dependence depends on scale; at larval resource patch and at whole population. Researches on Population Ecology 35, 261-271.

Tuda, M. (1998) Evolutionary character changes and population responses in an insect host-parasitoid experimental system. Researches on Population Ecology 40, 293-299.

Tuda, M. (2003) A new species of Callosobruchus (Coleoptera: Bruchidae) feeding on seeds of Dunbaria (Fabaceae), a closely related species to a stored-bean pest, C. chinensis. Applied Entomology and Zoology 38, 197-201.

Tuda, M. (2007) Applied evolutionary ecology of insects of the subfamily Bruchinae (Coleoptera: Chrysomelidae). Applied Entomology and Zoology 42, 337-346. 
Tuda, M. \& Iwasa, Y. (1998) Evolution of contest competition and its effect on host-parasitoid dynamics. Evolutionary Ecology 12, 855-870.

Tuda, M. \& Morimoto, K. (2004) A new species Megabruchidius sophorae (Coleoptera, Bruchidae), feeding on seeds of Styphnolobium (Fabaceae) new to Bruchidae. Zoological Science 21, 105-110.

Tuda, M. \& Shima, K. (2002) Relative importance of weather and density dependence on the dispersal and on-plant activity of the predator Orius minutus. Population Ecology 44, 251-257.

Tuda, M. \& Shimada, M. (1993) Population-level analysis on reduction in equilibrium population size of the azuki bean beetle. Researches on Population Ecology 35, 231-239.

Tuda, M. \& Shimada, M. (1995) Developmental schedules and persistence of experimental host-parasitoid systems at two different temperatures. Oecologia 103, 283-291.

Tuda, M. \& Shimada, M. (2005) Complexity, evolution and persistence in host-parasitoid experimental systems, with Callosobruchus beetles as the host. Advances in Ecological Research 37, 37-75.

Tuda, M., Chou, L.-Y., Niyomdham, C., Buranapanichpan, S. \& Tateishi, Y. (2005) Ecological factors associated with pest status in Callosobruchus (Coleoptera: Bruchidae): high host specificity of non-pests to Cajaninae (Fabaceae). Journal of Stored Products Research 41, 31-45.

Tuda, M., Matsumoto, T., Itioka, T., Ishida, N., Takanashi, M., Ashihara, W., Kohyama, M. \& Takagi, M. (2006a) Climatic and inter-trophic effects detected in 10-year population dynamics of biological control of the arrowhead scale by two parasitoids in southwestern Japan. Population Ecology 48, 59-70.

Tuda, M., Ronn, J., Buranapanichpan, S., Wasano, N. \& Arnqvist, G. (2006b) Evolutionary diversification of the bean beetle genus Callosobruchus (Coleoptera: Bruchidae): traits associated with stored-product pest status. Molecular Ecology 15, 3541-3551.

Utida, S. (1954) 'Phase' dimorphism observed in the laboratory population of the cowpea weevil, Callosobruchus quadrimaculatus. Oyo Dobutsu Zasshi 18, 161-168. (in Japanese with English summary).

Utida, S. (1965) 'Phase' dimorphism observed in the laboratory population of the cowpea weevil, Callosobruchus maculatus. IV. The mechanism of induction of the flight form. Japanese Journal of Ecology 15, 193-199. (in Japanese with English summary).
Utida, S. (1966) Water content of body in several kinds of the bean weevil. Japanese Journal of Applied Entomology and Zoology 10, 39-43. (in Japanese with English summary).

Utida, S. (1969) Photoperiod as a factor inducing the flight form in the population of the southern cowpea weevil, Callosobruchus maculatus. Japanese Journal of Applied Entomology and Zoology 13, 129-134. (in Japanese with English summary).

Vamosi, S.M. (2005) Interactive effects of larval host and competition on adult fitness: an experimental test with seed beetles (Coleoptera: Bruchidae). Functional Ecology 19, 859-864.

Vamosi, S.M. \& Lesack, T.L. (2007) Direct effects of larval competition on development time and fecundity in seed beetles. Evolutionary Ecology Research 9, 1131-1143.

van Asch, M. \& Visser, M.E. (2007) Phenology of forest caterpillars and their host trees: The importance of synchrony. Annual Review of Entomology 52, 37-55.

Watanabe, N. (1985) Oviposition habit of Sulcobruchus sauteri (Pic) and its significance in speculation on the pre-agricultural life of seed beetles attacking stored pulses (Coleoptera: Bruchidae). Kontyu 53, 391-397.

Wilson, R.S. \& Franklin, C.R. (2002) The detrimental acclimation hypothesis: response. Trends in Ecology E Evolution 17, 408.

Xie, S.-P., Deser, C., Vecchi, G.A., Ma, J., Teng, H. \& Wittenberg, A.T. (2010) Global warming pattern formation: Sea surface temperature and rainfall. Journal of Climate 23, 966-986.

Yanagi, S. \& Miyatake, T. (2002) Effects of maternal age on reproductive traits and fitness components of the offspring in the bruchid beetle, Callosobruchus chinensis (Coleoptera: Bruchidae). Physiological Entomology 27, 261-266.

Yanagi, S. \& Tuda, M. (2010) Interaction effect among maternal environment, maternal investment and progeny genotype on life history traits in Callosobruchus chinensis. Functional Ecology 24, 383-391.

Yoshida, T. (1990) Historical review of bruchid studies in Japan. pp. 1-24 in Fujii, K., Gatehouse, A.M.R., Mitchell, R., Johnson, C.D. \& Yoshida, Y. (Eds) Bruchids and Legumes: Economics, Ecology and Coevolution. Dordrecht, The Netherlands, Kluwer Academic Publishers.

Yukawa, J. \& Akimoto, K. (2006) Influence of synchronization between adult emergence and host plant phenology on the population density of Pseudasphondylia neolitseae (Diptera: Cecidomyiidae) inducing leaf galls on Neolitsea sericea (Lauraceae). Population Ecology 48, 13-21. 